DOI: 10.20472/IAC.2017.034.061

FAYYAZ ZAHED

Central Tehran Branch.Islamic Azad University, Iran (Islamic Republic of)

NEDA MORADI

islamic azad university.science and research branch tehran, Iran (Islamic Republic of)

\title{
THE EFFECT OF WORLD WAR I ON IRAN SITUATION
}

\begin{abstract}
:
Abstract

The World War I had a considerable influence on the history of many non-European countries specially Iran. Iran hoping that not to involve in this world war, neutralized in the war at the behest of November 1st in, but abjuring it by hostile countries, Iran was changed into an extended from for imperialist powers.

Consequently was invaded by Britain, Russia, Ottoman and Germany from the south, north, and west. The World War I caused numerous problems for Iran. Increasing external pressures, the weekness of central government and subsequently, cabinets instability and economic crises added to the complexity of the situation. Despite Iran's efforts to keep himself from the battle of which had no proportion and no effect on it, the juggernaut strikes inflicted on political stability and consistency of the government and incurred formidable losses on the economy of this country. October revolution which at first seemed to improve the situation of Iran, caused Britain totalitarianism and changing negative balance. This created a long- term gap in Iran political arena and finally lead to 22th feb coup, and also overthrowing Qajar regime and replacing it with Reza Pahlavi. The event that changed the procedure of constitutional revolution and Iran Policies landscape.
\end{abstract}

\section{Keywords:}

Keywords: World War I, Iran, Qajar, violations of neutrality, political and economic crises. 


\section{Introduction}

The World War 1 brought over many calamities. Millions of people in all over the world, lost their lives over of European powers battles. Iran, although, neutralized in the beginning of contention, but this decision was never recognized by great powers. Although they claimed some influence rival powers such as Ottoman Empire and Germany in Iran, but we know that those claims was all excuses.

Iran's neutralization was not respected because Iran had no military, economic and political power to support its ideas in international arena. There were no dynamic economy and heartwarming policy in the country and the Constitutional revolution, however, was a lightning of hope but it was a hurried country that disorganized the situation. Not with standing, it seems that Iran, alongside other Asian countries and third world were the main victims of this life struggle. Neither Iran and nor other independent state in the world had a position in this battle of place. Their countries were attacked so the flame of uncivilized battle of European governments also pulled to their realm, each in turn. Because Iran was in Russia's neighborhood and also the India's line defense, had a greater share. Thousands of people died but nobody commemorated them. Even after the victory, Iranian portion was not contributed from this battle and Iran interests was immolated for Russia and England coveting. Although They Iran deceived in the war, but they did not imagine a portion for them. It is much bitter that the governments which entered aggressive armies to from and contravened Iran neutralization, even had not admitted Iran,s delegation to Versailles treaty! This short article attempts to explain part of these problems.

\section{Entrance}

The World War I has presumably commenced in back alleys of Sarajevo after a shoot on Austria prince on August $3^{\text {rd }} 1914$. This shoot was the only excuse beginning of the war. Because the causes of the war was already provided. The event was started only 8 days after the coronation of Ahmad Shah Qajar and prime minister Mostofi ol-Mamalek. From the beginning of the war up to starting constitutional revolution just passed 8 years. Three years of this period were expended upon antagonism contention for ending bombarding congress event shelling parliament and tyranny. It seems that five years must not be a lot of time for the failures or disappointment in affair of a democratic revolution. But the story was different in Iran. If the world was tired at the end of the World War I, Iranian had gotten out of breath before facing this frightening phenomenon (Katouzian, 2013: 111). The revolution had not resulted in what Iranian wished. As a result of revolution, the social and political organization of the society was in disarray. But there was no order and prosperity against this agitation (Houshang Mahdavi, 1998: 30). The revolution not only could not bring causes of freedom, but also dunked the society in tribal conflicts and 
social instability. The revolution although had the aspects of a seemingly civil revolution, but before being born, it was sick, and defective. The revolution was accomplished to overcome domestic tyranny, but was caught in the heart of the "Villeinage" system and a veteran bureaucracy of the court. A look at the combination of social forces who formed the congress shows that revolution has not been able to rescue himself from the claws of traditional system ideas (Abrahamian, 1998: 95). Suffice it to look at the social combination of assembly members. On the other hand, this is the historical aspect of the Iranians that are attendant in negating current situation and have not had a clear plan in the quality of deployed system. Iran society after the revolution fell into anarchy and pluralism (katuzian, 1373: 7). There was no compromise among political forces theoretically and who had different economical interests. Absence of maturity and expansion and lack of the culture names national interests that can be overcome to some extent on internal conflicts, marginated the revolution function (Kermani, 1992: 548). Political dissensions in two democrat and moderation groups, was rooted in calss interests and to some extent in their social origin more them theoretical conflicts. We should add colliding social order to this collection (Abrahamian, 1998: 95).

The revolution not only did not result in improving economic situation but caused decreasing product via emasculating traditional landlord and tenant system and political anarchy. Iran society at the time of researching was mainly rural and the only minority of social forces were in the group of urban people. Dependence of social and political forces of Iran on agriculture and lack of modern and civic economy was effective in weakening reformists (Shamim, 1995: 443). If we understand the role of traditional and agricultural institutions, we will find out that the revolution disturbed the old order and was not able to present an immediate and effective solution. This process even could not answer increasing requirements of the society. Sir Percy Sykes pointed out to the bad state of affairs. He claims that there was not an army and people had no energy and there was no money in treasury at the beginning of the World War I (Sykes, 2001: 125). We got used to regard the lean application from foreign countries by Qajar Kings as their leaning towards travel, fleshpots, and courtier ogling.

We are unaware that some of these travels were suggested by reformists and honor characters in order to take Iranian kings in contact with global changes. It does not seem that the expense of an European travel for a kingdom is so terrible that we regard it as the misfortune of Iran. As we latitudinally got used to present a despised, womanizer and helpless image from Qajar kings alongside with historical demolition of pahlavid era historians. The kings who donated cities to Russia only at the price of 17 blue-eyed girls. This decreasing of understanding, was the main reason of these historical miseries. Meanwhile everybody can well understand that in seraglios of Qajar kings where there were more than 300 very eye catching girls, certainly some blue-eyed beauties could be found! 
Moreover, some tensions before World War I had weakened political society of Iran. Constitutional aspirations were not fulfilled. Autocratic government gave his place to the men of speaking. There were no place for men of act. Not because revolution men in comparison whit the past had no virtue, but dualities and disunions dramatized all of them like infirm individual who came to the scene, constitute a government, then dedicated the scene to another one (Keddie, 2008: 179).

\section{Iran and the World War I}

On August $6^{\text {th }}$ in 1914 when the World War I started, the first reaction of Iran after announcing of neutrality the war, was neutralization in a treaty on November $1^{\text {st }} 1994$ (Atabaki, 2011: 14). The next day, Alaol-saltaneh foreign minister, announced this matter to all foreign embassies (Majd, 2011: 33), and then all cabinets emphasized this matter. But it was clear that neutralization's had no meaning while Russia Army did not go out of Iran. Actually, not war parties nor nationalists especially democrats who asked for declaration of war against the Allies, did not care for the neutralization (Ettehadieh, 2010: 22).

Miroshnikov wrote about neutralization Iran:

But it turned out this neutrality as we shall see was not more than a dream, because all hostile powers contravened Iran neutralization without bearing any punishment and Iran government was not always really neutral (Majd, 2022: 73).

At this time. Iran just seemingly regarded as a independent country. Ahmad shah was newly 18 and enthroned and had no vegal powers. About 7000 Russian soldier who were in the northern provinces for different purposes, according to the treaty of Russia and England 1907, granted certain privilegesand rights for themselves (Bahar, 1371: 7). The English also reigned in the south of Iran and the decree of the Iranian governmentwas just valid in areas that determined as neutral. Starting the World War I the Russian who struggled with Ottoman, entered its forces to Iran regardless of Iran objection and at the end of 1914, about 70000 Russian soldiers occupied northwest of Iran across the border with ottoman. England also entered army from the south into Khuzestanand attack Ottoman conquests in Mesopotamia (Mahdavi, 1377: 345). Attacking Ottoman armies to Iran and after a war between Russia and Ottoman forces near Tabriz, the Russian had to evacuate the city. In this war, Tabriz was set on fire in during the war and people damaged severely. The Russian forces who with drawn near Jolfa, attacked again when backup troops arrived and after defeating Ottoman forces in south of Jolfa, occupied Tabriz again on $30^{\text {th }}$ Jan of 1915 . Then, Russian troops moved toward the west and in the spring of 1999 recaptures Rezaeieh from Ottoman and moved forward near Lake Van. 
Russian troops on 8th December 1915 moved to Tehran from Qazvin and entered Karaj. After moving the Russian troops toward Tehran many dignitaries and parliament representatives moved toward Qom and established national defense committee there (Shamim, 1995: 558). Besides, approaching Russian armies to Tehran, the decision for changing the capital was made. But on 23 November Russian and England plenipotentiary visited Ahmad shah and dissuaded him from transporting capital to Isfahan. (Ibid, 559)

Asre jadid paper that had a conservative stance and allocated its first page to the to war and European countries, wrote in an article:

Is the meaning of neutralization that Russia occupies northern part of our country and England the southern and also Ottoman entered its army in the west? Then, if we wanted to be neutralized as so do we, it is obvious that they do not let (Sheikh Nuri, 2013: 205).

The reaction of the Iranian political dignitaries to the occurrence of war can be found in three different groups:

1. Radical minority tended to an alliance with the central powers.

2. The conservatives claimed, it is beneficial for the country to remain passive and support the Allies in this way.

3. The moderates who was annoyed by Russia and England interference as much as radicals, but were more cautions in choosing tactics and believed that explicit animosity with the allies results in complete colonization and country decomposition (Katouzian, 1392: 111).

\section{Instability from inside and pressure from outside}

The cause of political instability occurrence in this period of time must be searched in different aspects. This condition resulted from the collection of complicated factors, internal or external in different levels.

This time, was not the period of continuous changes, but it was the time of unsettled and unbalanced upheavals resulted from internal behavior and external interferences (Katouzian, 2013: 111). Internal revolt and external interference resulted in socialeconomical and psychic insecurity that its reflection was greed and corruptionof afterrevolution governments (Ibid, 113).

But according to the framework of Iranian tyranny which believes that Iran always involved in cycle of tyranny, revolution and chaos.Again disorder engulfed allover the world, among these disaffections and interference of foreigners, was this the starting of 
the world war I, that stabbed last shot in the coffin of the Iranian people and the constitutional (Katouzian,2022: 62).

In this period, we observed the instability of political sovereignty whose symbol was cabinets. Iran government was powerless and the cabinet change rapidly, because no one could get vote of confidence from the assembly (Ettehadieh, 2010: 22). From 6 ${ }^{\text {th }}$ August 1906, when Mozaffar ad-Din Shah signed the order of constitution to coup d'etat an $22^{\text {th }}$ February 1921, it means in a period of less than 15 years, the executive power of political system was involved in crisis 51 times. ${ }^{1}$ It is interesting to know that the lifetime of cabinet in 33 cases were less than 100 days. In second period Mirza Hassan Mostowfi ol-Mamalek came to power after Ahmed Shah crowning and at the beginning of world war I. Starting ruling, he had many different problems with two belligerent powers (Sheikh Nuri, 2013: 201). Mostowfi ol-Mamalek tried to keep Russia and England satisfied and if possible, satisfy satisfaction of the democratic germanephile in the assembly (Majd, 2011: 73). In unsettled situation after military attack of England, Russia, and Ottoman to Iran in the first months of the war, the assembly tried to pretend that everything is ok via preparing and planning the collection of financial, military and educational reforms, notwithstanding this and despite government attempts, the period of cabinet was very short. Mostowfi's cabinet on 20th Feb 1915 after charging several minister presented to the assembly to get confidence vote. Caldwell on 20 March notified the resignation of Mostowfi's cabinet and nominating a new cabinet ruling Moshirodolleh (lbid, 125).

After a short time the English and Russian found that there is no different between this cabinet with Mostowfi's cabinet. They were dissatisfied from Moshirodolleh reaction to Germany activities inside Iran and because of this they tried to overthrow his cabinet. Moshirodolleh who could not resist Russia and England pressure, resigned on $1^{\text {st }}$ may 1915 and Eyn-ed-Dowleh was supplanted ${ }^{2}$ (Ibid, 125-129). Eyn-ed-Dowleh's cabinet had faced many problems from the beginning because of the severe diplomatic and military pressures and assembly distrust.

Miroshnikov writes:

This cabinet was unable to continue the maneuver between Russian and English representatives on the one hand and German's diplomats and assembly members on the other hand. Eyn-ed-Dowleh's cabinet resigned after a long crisis and once again Mostowfi ol-Mamalek whom the England and Russian were not satisfied with ${ }^{3}$ (Majd, 2011: 149).

This changing showed that no these politicians one able to solve these problems in such a way that can get the level of legitimacy to prepare the possibility of political convocation

${ }^{1}$. In some works number of cabinet listed differently. 
and nor Iran has authority and option internationally to resist against invadercountries flaunting. Meanwhile, there was no integrated policy for in dealing with Germany and Ottoman governments. Ottomans was not accepted by public opinion because of longterm wars in Safavid era and after that. Only some politicians envisaged the theory of Islam union can be effective. Germany just misused Iran to expand the battle in different parts of the world. Nevertheless, this has not changed into a general and common policy in Iran.

In 1915 struggling between the Allies and central administrationsto conquer on the government and capital of Iran flared up gradually. The influence of the German increased little by little so that dismayed the minister plenipotentiary of Allies about a German coup d'etat. To avoid this from happening, in $7^{\text {th }}$ November russian troops stationed in Qazvin moved towards Tehran.The news Russian advance Tehran in horror swallow. The fans of assembly and people intended to organize a collective wander from the capital and establish another government away from the Russian accessibility. A large group of assembly representatives, officials and millions and their armed fans, officers and soldiers of the gendarmerie and the embassies staff of Germany, Austria and Ottoman embassy left Tehran and went to Qom then Isfahan (Cronin, 2010: 71) and this movement called immigration, and these immigrants among Germans to group "incomprehensible" were famous (Dailami, 2010: 169). Then Mostowfi ol-Mamalek tried to satisfy representatives to come back to the assembly but he could not and the assembly closed because it does not have the minority members. Mostowfi ol-Mamalek resigned and in Dec 1915 Farmanfarma the anglophile politician, was replaced him. Continuing the Russian advancing toward karaj that caused frightening and group excaping mass escape of people,

Caldwell notified via telegram on this matter on Nov 17 that:

«The Russia Army in near Tehran. Iranian King and statesmen tend to exit but one in suspension still. German minister plenipotentiary and Ottoman ambassador escaped ...».

He reports [Nov 18] immediately.

«Majesty is dubious between two decisions: Democrats such as prime minister and the others recommend him to exit from Tehran and war minister (Sepahdar) and other centrists and Russian fans donot affirm this action and threaten him that of the king gets out of Tehran, they will enthrone one of the pretenders from royal family instead».

$\mathrm{He}$ (Caldwell) notifies that about ten significant democrat members of parliament left Tehran. Caldwell informed parliament break-up on 29 Nov 1915 and lays that they (democrats) under the leading of Soleyman Mirza who is a democrat, are organized in Qom (Majd, 2011: 158-160). Meanwhile, immigrants with German support, constituted a national defense committee presided over by Solayman Mirza, the democrat leader (Ettehadieh, 2010: 24). The immigrants had not exited from Tehran that people in Shiraz 
controlled the government via gendarmerie coup d'etat. In 1915 the influence of democrats and German ophiles increased in Shiraz. In that city like elsewhere, established revolutionary organizations called the committee of Iran Independence protectors, on the other hand, in south and west of Iran gendarmerie officers rose in revolt and occupied Hamedan, Kermanshah, Soltan Abad, Isfahan, Yazd and kerman and made the Allies nationals to leave the cities. Meanwhile Russian Army that caused immigration made the populists who was under the colors of national defense committee, to withdraw from Qom to Hamedan and then Kermanshah. In Kermanshah, a provisional government headed by Nezam ol-Saltaneh was established that most of its members were Democrats.Apparently non-stop advancing of Russia continued and the interim government had to withdraw from Kermanshah.

Nezam ol-Saltaneh and the populist had to apply for a sylum in Ottoman territory and in May 1916 resided in Baghdad temporarily. In August 1916 central governments made Russia to withdraw by an attack. Nezam ol-Saltaneh returned Kermanshah following Ottoman army and reconstituted interim government again. This time he abided six months (Cronin, 2010: 75-76).

Farmanforma cabinet resigned on $3^{\text {rd }}$ march1916 when Russia occupied Kermanshah. In $13^{\text {rd }}$ march1916, Caldwell notified the appointing Sepahsalar (Mohammad Vali khani Tonekaboni, his former title was Sepahdar the great) as the president of cabinet in 1915 and sent the name of cabinet members to U.S foreign ministry.

In his next report, Caldwell wrote about new cabinet:

«New cabinet presided by Sepahsalar great is more satisfactory than former cabinet presided by Farmanfarma for who are inclined to a cabinet partial to Russia» (Majd, 2011: 250).

In August 1915, Sepahsalar cabinet that had been seized the power in March 1915, had to resigned. Sepahdar cabinet which was apparently Russia adherent, speculated on trying his chance.

Kofriin report informed of simultaneous suggestions of Iran to Allies and central governments:

«I got informed from reliable sources that the Iranian government has propounded to Allies governments that if they guarantee Iran sovereignty and independence, the Iranian government declares war on Ottoman Empire. on the other hand and of course without the Allies announcing, these Iranian officials also suggested to central powers that if they guarantee Iran's independence, Germany and its allies will be prospered from Iran spiritual supports, provided that Turkish forces do not come nearer than Hamedan. Whereas the representative of central governments in Tehran are not able to have contact with their states, Iran foreign minister sends 
necessary telegrams to Iran minister plenipotentiary in Vienna and ordered him to contact with Austria and Germany Governments of this matters. There is no answer from Vienna yet».

Russians and English who become enraged from this maneuver of government, made Sepahsalar cabinet resign and appointed Vosoghodoleh instead. Sepahdar lacked necessary will and enterprise to exert effort in affairs, which had been taken into consideration by Mirza Yahya Dowlatabadi (Dolatabadi, 1992: 180). Russian politicians knew him as the fan of Russia and England regarded him as a puppet. Thus, a new government came to power that was balanced with Russia and England in his policies (Majd, 2011: 196) Kasravi lays one of the most important causes of Vossug cabinet instability and finally his decline, new and anti-formation classifications in the beginning of reopening forth parliament and the attempt of this group to go to parliament via making government appointing their relatives as the governor of different cities by up roaring on newspapers. Whereas the matter of frightfulness and murder in punishment committee became into a big problem (Kasravi, 2009: 770).

Vossuged Dowleh had not yet started this job that he could not have a suitable reaction to the commitments which Sepahdar had given to both, Russia and England, then he granted his place to another one (Bahar, 1992: 29).

Of course, again to himself. In just one year, cabinets of Alaol-saltaneh, Eyn-ed-Dowleh, Mostowfi ol-Mamalek, Samsam and Vossug constituted from 1956 to 1957 (lbid, 28).

\section{Economy in Crisis}

One of the causes for the ineffectiveness of the government in solving internal problems and consequently instability and uncertainty of cabinets was financial problems, lack of budget, and lack of equipped military forces with a suitable commander, that these problems curtailed the governments to obviate the problems and many of them had to resign because of unability in solving these problems. At the beginning of the war, Iran government involved in financial crunch, because the war resulted in severe decrease in foreign trade/ and customsincomes. Moreover inability in collecting taxes. Lack of determined budget and stopping foreign trade, war and presence ofOttoman armies in Iran, made this situation more critical (Ettehadieh, 2010: 35).

Consequently, legal deadline contract signed between Iranand Russia and England. Southern and northern Customs incomes collected (Respectively) by Russia and England. Profits and delay charge of Iran debts to England and Russia was cut from the incomes and the remainder was paid to Iran. Whereas according to this contract, the whole income must be paid to Iran government. Decreasing commerce because of the war, this paying was really a little. Besides, Iran has started oil production in 1913 and 
rapidly charged into a country exporter and producer of oil. The concession of Iran oil was for English and Iranian oil Company and two-third (2/3) of stocks of company in 1914 belonged to Britain. Immediately after starting the war in 1914, England not only stopped paying Iranian share, but also they claimed 2 million dollars as a compensation for the damaging of pipelines by quarrelsome tribesmen. Depriving from oil incomes along with cheating and disarray in exchange rate, completed economic plight of Iran government; consequently, in the thick of the war and famine, Iran government could not take an effectual and advantage as action for victims (Majd, 2008: 27).

Caldwell wrote in a report dated 7 October 1914 on the effect of war on financial resources of Iran:

«Iran is in a critical situation economically.Europe war has stopped all incomes of duties of imports and exports, and it is mentioned that government bankrupted.Any way the parliament which is to be constituted will find out a solution for this problem».

Christian Science Monitor also in edition of 2 Mars 1915 quoted from anonymous source in London mentioned some points about financial circumstances of Iran:

"Ofcourse, the main problem of Iran is the big financial problem. As far as it is related to the government, the question is not just collecting taxes, but the bigger problem is respecting justice in expense after collecting them» (Ibid, 165).

The war had pernicious effects for Iran. As declared before no one respected Iran neutralization. During 4 years of world war, 8 government came to the power in Iran, it means one government in 6 month. This shows what circumstances Iran has. The war for Iran had another afflictionsalso. The most important of them the horrible famine that can be regarded as a genocide.

Denstrvil who served in north force under the supervision of Ironside declared the rate of this demolition very extensive. Invader armies bought whole corps in market to support fronts.

They applying military influence and current corruption in political bureaucracy of Iran, got products withtheir bloody money. This caused a great famine in Iran, So that Denstrvil claimed that some of the Iranian who survived from the famine, alleviated their hungry in pastures (Avery et al., 2009: 397).

Ahmed Kasravi believes that Iran population decreased to one third in these years. Supposing that Majd's studies on death rate and casualties resulted from the Allies presence are exaggerating, undoubtedly this war inflicted destroying blow on the social, political and economic body of Iran. Moral disasters resulted from this crisis one another subjects. This situation is more understandable when we know that in these years $90 \%$ of 
labor forces were in agriculture and handy crafts and $10 \%$ were in trading and civic services (Katouzian, 2013: 73).

But it is evident that finishing war in 1918 Iran faced a crushing crisis. The country's treasury was emptier than ever. The population decreased to 1/2. Political anarchy has crippled the country. From constitution revolution just remained only a memory!

Social gaps showed great faults (Shuster, 1983: 348). Events happened between traditionalists and modernists that according them was impossible. Political statesmen lacked efficiency and also were disable to change the condition. The king who claimed to be democrat, but was a fake copy of constitution. Because he has no congruence with the other pillars of the power. Meanwhile, happen revolution October 1917, had changed international circumstances. Now Britain intended to become the absolute power in Iran. But this facing was impossible. Northern forces must withdrew. Britain forces severe oppositions in Mesopotamia and levant. England economy got weak and the soldiers were fatigued. The flash of council government was observed. The enthusiasm of political changes was so high that the establishing a central government for tired patriots and foreign forces was necessary (Zahed, 2010: 37).

\section{October Revolution}

Iran was so strategic for both Russia and England. Ottoman and Germany also could profit of this strategic credit. But the condition was not according to Iran's desire. Starting the war, two invader government which had divided Iran into 3 parts in contract 1907, brought about the means of secret contract 1915, fearing Germany's influence, and performed it. In this contract Iran divided into two penetration areas and the most part of Iran allotted to Russia. Here it can be understood that Iran was only a winning trump for England to safeguard Britain interests in India and to keep dominion on south oil (Houshang Mahdavi, 1998: 348).

Meanwhile, perhaps only Iran was fortunate that October revolution happened in Russia and Czar Russia replaced with by Bolsheviks. Now Czar forces exiting from Iran. This caused a power vacuum that changed England into the main actor of domestic and foreign policy of Iran. Iranian reaction to the revolution was positive. Immediately they send a congratulation telegram to Russia Duma by the name of Iranian national representatives. Iran was the first country that officially recognized the revolution (Shamim, 1995: 570). Although it must be forgotten that Russia in time of Lenin involved in domestic problem and when engaged in foreign affairs specially Iran, there was no difference with Czar policies. Iranian were disaffected by 1907 contract and now this government downfall survived their hopes (Ibid, 573). 
Exiting Russia from Iran England had a dual reaction. On the one hand, they were glad to defeat the opponent and vacancy of the arena and on the other hand they were worried about exiting Russia vapidly and north areas emptiness without any firm defense line. Now this was England who underwrote the amount of 100.000 Tomans monthly help to Cossack army that Russia had under written before. Then England transferred his general staff to Qazvin, In order to access the way of Baghdad, Qazvin, Rashtaswell tale an action against Russian Communists if necessaryand also prevent Ottoman advancing (Houshang Mahdavi, 1998: 352).

All these matters can be a background for settling 1919 contract. The contract which sentenced to death in spite of Vossuged Dowleh attempts and advocates like Malekoshoara (Mostofi, 2007: 167). The contract could not be accepted despite of Iranian conceptual about England. Although writers such as Katouzian believed that the contract had no suitable propaganda. If it was not so, it would be possible to be accepted (Katouzian, 2002: 315). The mentionedcontract contained 6 terms and also had one addition treaty on how pay two million English Lear loan to Iran (Hedayat, 1984: 336).

But not Iran's king nor statesmen and not media and not national council representatives agreed with that. We can add Russia, France and the US to this group, which regarded this contract as in contradiction to their benefits (Katouzian, 2002, 316). But it is clear that it was a new plan from Lord Curzon and hiding from India's viceroy and only laying on close relations with Vossuged Dowleh. Even if we have no doubt about the commissioners of the contract, exchanging huge amount of money by name of presents and bribe, ambivalence about this contract and advantageous intentions will be questioned (Sheikh ol-eslami, 1993: 247). Although, this contract recognized Iran independence in its first paragraph, but accepting that Iran had to employ two English counselors for supervising their actions, increases concern about Iran dependence (Ibid, 316). But the contract defeating was not the finale. Coup d'etat 22rd Feb 1921 can show how effective the defeating this contract can be in fulfilling new political programs in Iran. The factors that caused the necessity of a powerful and centralized government from an internal viewpoint and Bolshevist revolution occurrence in 1917 and armistice in 1918 from an international viewpoint, necessitated the necessity of establishing a centralized government in Iran. The task that was ascertained by coup d'etat.

\section{Conclusion}

The war did not concern Iran and its nation. At least those who governed in Iran, supposed so. But this was incompatible with current realities of policy and international. On one hand Iran was Russia's neighbor and on the other hand, India's anti-shock. The matter which caused Britain policy attention during last century. Iran notified his 
neutralization, but they neither have logistic and military power nor suitable economic authority to dictate their decision to quarrelsome pretenders.

More than involved countries which maybe underwent expenses, the war had terrible effects on Iran. Because involved countries hoped that in case of victory they will be able to compensate the losses. But, what about Iran? Iran was just the partner of expenses and disasters of the war.

Besides Iran faced the war in an unsuitable time. There was no suitable leadership, no proper general awareness, to make a decision at least. Those countries immodestly did not let the representatives of Iran present in peace treaties. Iran was the place to struggle between Russia, Britain, Ottoman and Germany while the effects of events after constitution and also after revolution remained to be solved. The first reaction was continuous government collapsing. Even, immigration was not effective the young king who was frightened of Russia, Even by threatening to exit from Tehran, could not keep his sovereignty. The king insistence to go to Isfahan and threatening to establish agovernment in exile could end to occupying the capital and changing reign. Meanwhile Russia revolution occurrence could be regarded savior. But Russia caused some effects either amid the revolution or when they came back to continue Czar policies, had no advantage for Iran. The October revolution commenced just with vain hopes, but, infact, it extended the crisis. Because it unsettled the Semi-bind negative balance which was of benefit to Britain.1919 contract and 1299 coup d'etat, maybe mere the reaction and reflection to this balance changing. The event that annihilated constitution revolution and set Iran in a new way.

\section{References}

Abrahamian, Ervand. 1998, Iran Between Two Revolutions, translate by K. Firouzmand and other, Tehran. Markaz publishing.

Avery, Peter., G. Hambly., and Charles Peter Melville. 2009, The Cambridge History of Iran (Qajar), translate by Teymour Ghaderi, Tehran. Mahtab publishing.

Atabaki, Touraj. 2010, The first world war, Great Power Rivalries and the Emergence of a Political Community in Iran, translate by Hassan Afshar, Tehran. Mahi publishing.

Bahar, Malek al-shoara. 1992, A Brief History of political parties (1,2), Tehran. AmirKabir publishing.

Dailami, Pezhmann. 2010, The populists of Rasht: Pan- Islamism and the Role of the Central Power, translate by Hassan Afshar, Tehran. Mahi publishing.

Dolatabadi, Yahya. 1992, The life of Yahya, Tehran, Attar publishing.

Ettehadieh, Mansoureh. 2010, The Iranian Provisional Government, (Iran and the First World War: Battleground of the geat power), translate by Hassan Afshar, Tehran. Mahi publishing. 
Hedayat, Mokhber al-Saltaneh. 1984, The report of Iran, By the effort Muhammad Ali Soti, Tehran. Noghreh publishing.

Houshang Mahdavi, A. 1998, Iran's foreign relations history, Tehran. AmirKabir publishing.

Katouzian, Muhammad Ali. 2002, Conflict state and nation; theory of history and politics in Iran, translate by Alireza Tayyab, Tehran. Ney publishing.

Katouzian, Muhammad Ali. 2013, The Political Economy of Iran: From Constitutional until the end of the Pahlavi dynasty, translate by M. R. Nafisi and K. Azizi, Tehran. Markaz publishing.

Keddie, Nikki. 2008, Qajar Iran and the Rise of Reza Khan (1796-1925), translate by M. Haghighat khah, Tehran, Ghoghnoos publishing.

Cronin, Stephanie. 2010, Iranian Nationalism and the Government Gendarmerie, translate by Hassan Afshar, Tehran. Mahi publishing.

Kermani, Nazem ol-Eslam. 1992, The History of Iranian Awakening, Tehran. Amirkabir publishing.

Kasravi, Ahmad. 2009, Eighteen-year-old history of Azerbaijan, Tehran, Hermes publishing.

Majd, Mohammad Gholi. 2008, The Great Famine (1917-1919), translate by Mohammad Karimi, Tehran, political studies \& research institute (PSRI).

Majd, Mohammad Gholi. 2011, Persia in World War I and its conquest by Great Britain, translate by Mostafa Amiri, Tehran, political studies \& research institute (PSRI).

Mostofi, Abdollah. 2007, The Story of My Life; The Administrative and Social History of the Qajar Period $(1,2)$, Tehran. Hermes publishing.

Shamim, A. S. 1995, Iran in the Qajar dynasty, Tehran, Modabber publishing.

Sheikh ol-Eslami, Mohammad Javad. 1993, Portrait of Ahmad Shah Qajar (1,2), Tehran. Goftar publishing.

Sheikh Nuri, Mohammad Amir. 2013, Anti-colonial movement south: Ayatollah Beladi Boushehri struggles against Britain in World War I, Tehran. Organization of Islamic Culture and Thought Research Publications.

Shuster, Morgan. 1983, The Strangling of Persia, Translate by F. Barzegar and E. raeen, Tehran. Safi Alishah publishing.

Sykes, Sir Percy. 2001, The history of Iran, translate by M. A. Fakhredaei Gilani, Tehran, Afsoun publishing.

Shuster, Morgan. 1983, The Strangling of Persia, Translate by F. Barzegar and E. raeen, Tehran. Safi Alishah publishing.

Zahed, Fayyaz. 2010, Golden Age of Iranian press, Tehran. Khaneye tarikh va tasvire abrishami publishing. 